\title{
Bases antropológicas da cidadania brasileira: sobre escola pública e cidadania na Primeira República
}

\author{
Lílian do Valle \\ Universidade do Estado do Rio de Janeiro, Faculdade de Educação
}

\section{Introdução}

Devido às fragilidades de sua implantação, não são poucos, no Brasil, a tratarem o regime republicano como simples continuação do período monárquico. Igualmente correntes, as críticas à tradição de constituição, no país, de um Estado forte e monopolizador concedem cores de fatalidade à idéia da formação histórica de um cidadão inexoravelmente passivo, tipo antropológico definitivo, a marcar os rígidos limites à democratização da sociedade brasileira. Seria, assim, cabal a impossibilidade de a escola pública formar cidadãos - todos os argumentos em contrário consistindo apenas em novas reedições do velho mito da demiurgia educacional? Ao tentar reunir os elementos para análise das construções antropológicas que estão na base da experiência de cidadania brasileira, este artigo coloca em perspectiva aquela que sem dúvida é a primeira e a mais central das exigências democráticas: a afirmação incondicional e incondicionada da igualdade política dos cidadãos.

\section{"Cem anos de ensino primário": a República em mal de identidade}

Em 1926, a Câmara dos Deputados festeja seu centenário em meio à reforma constitucional que o governo de Arthur Bernardes, já em final de mandato, promoverá: essa curiosa comemoração em que se lança um parlamento republicano, afirmando suas origens na instituição monárquica, não é, porém, fato isolado. O período é fértil desses grandes balanços, que de certa forma enfatizam a timidez de realizações do regime republicano. A fragilidade dos primeiros momentos, caracterizada não só pela instabilidade em que as lutas políticas lançavam o governo, mas pelos levantes internos e pelos conflitos externos, ${ }^{1}$, havia sido substi-

${ }^{1}$ Entre os levantes internos que marcaram o início da República, destaque-se aquele que levou à renúncia de Deodoro da Fonseca e ascensão de Floriano Peixoto. Tal instabilidade política levou o país à luta armada: à Revolta da Armada e à Revolução Federalista. No plano externo, o país ainda negociava a posse de determinados territórios. Da mesma forma, durante o período florianista, o país rompe relações com Portugal. 
tuída, com a definitiva derrota do florianismo, pelo compromisso que, unindo setores liberais às oligarquias tradicionais, impõe, pela "política dos governadores", 2 o fortalecimento dos poderes locais em detrimento da unificação republicana. A vitória do princípio da descentralização demonstra a grande força de recomposição de que as estruturas de dominação tradicionais são capazes, sobrevivendo à Monarquia e realizando novas alianças para monopolização do poder; mas ela também produz, na nova organização, suas próprias desigualdades, não só em termos das profundas diferenças regionais que alimenta, mas também das que, em razão do predomínio crescente da economia do Sudeste, ${ }^{3}$ passará posteriormente a instituir.

As tristes evidências de uma continuidade mais do que simbólica entre a Primeira República e o período monárquico fazem-se particularmente evidentes na área educacional, a tal ponto que, para muitos, o sentido das primeiras décadas do século dissolve-se inteiramente nos tempos que as precederam e naqueles que as sucederão:

2 "A implantação do regime republicano não provocou a destruição dos clãs rurais e o desaparecimento dos grandes latifúndios, bases materiais do sistema político coronelista. Ainda mais: instituindo a Federação, o novo regime viu-se obrigado a recorrer às forças representadas pelos coronéis, provocando o desenvolvimento das oligarquias regionais, que, ampliando-se, se encaminharam para a 'política dos governadores'. Assim, os 'homens mais importantes do lugar', pelo seu poderio econômico, político e social, mantiveram-se mais fortemente ainda como chefes das oligarquias regionais e, dessa forma, atuaram como as principais forças sociais no âmbito dos governos estaduais e federais" (Nagle, 1974, p. 4).

${ }^{3}$ "Como se sabe, a economia cafeeira se forma no segundo e terceiro quartéis do século XIX, quando surge como nova fonte de riqueza para o País. Principalmente depois da instalação do regime republicano, o café constituía a principal mercadoria que, no comércio exterior, fornecia a maior quantidade de divisas. Desde cedo, dois estados - Minas e São Paulo - se destacaram na produção cafeeira” (Nagle, 1974, p. 13). A partir de 1906, com o Convênio de Taubaté, a "unidade política" que o Estado brasileiro logra realizar reduz-se à política intervencionista de valorização da produção do café.
O período de quarenta e um anos iniciado em 1889 constituiu funcionalmente um prolongamento do Império, embora - esta a sua principal e nova característica - já como ponto de chegada na longa preparação que atravessava seu quarto século [...] (Chagas, 1978, p. 25, grifos nossos)

Nesse contexto, como considerar a recapitulação a que se presta Afrânio Peixoto, por ocasião dos festejos da Câmara, celebrando os "cem anos de ensino primário" no país, senão como o irônico registro de um só histórico descaso pela educação, que a inoperância das sucessivas leis só faz confirmar? Mais ainda, sob certos ângulos, a perspectiva legal só faria tornar o confronto mais desabonador para os primeiros anos da República, em razão da abolição do princípio mesmo da obrigatoriedade do ensino primário $-{ }^{4}$ pelo qual o novo governo republicano se exime formalmente da exigência educacional historicamente afirmada pelo Estado brasileiro...

O ponto de origem desses "cem anos" de ensino primário se situaria, assim, no voluntarismo monárquico que, já na Constituição Outorgada de 1824, pretendera torná-lo, pela simples força da pena imperial, gratuito e, a partir de 1827, data da primeira lei geral de ensino, obrigatório em todas as cidades e vilas mais populosas; mas também no Ato Adicional de $1834{ }^{5}$ que, inaugurando a duradoura ambigüidade com que

${ }^{4}$ Como observa Fernando de Azevedo (1963, p. 561), as urgências republicanas se concentraram, inicialmente, na consolidação do regime, na manutenção da ordem e na estabilização financeira abaladas, como já destacado, pelos difíceis primeiros anos da República.

5 "Do ponto de vista educativo, o Ato Adicional aprovado em 6 de agosto de 1834 e que resultou da vitória das tendências descentralizadoras dominantes na época, suprimia de golpe todas as possibilidades de estabelecer a unidade orgânica do sistema em formação que, na melhor hipótese, 'há de estarem as províncias em condições de criá-los', se fragmentaria numa pluralidade de sistemas regionais, funcionando lado a lado - e todos forçosamente incompletos - com a organização escolar da União, na Capital do Império, e as instituições nacionais de ensino superior em vários pontos do território" (Azevedo, 1963, p. 566). 
o Estado brasileiro reconhece a necessidade educacional, atribuíra a responsabilidade por sua organização e manutenção aos poderes regionais.

Em seguida, a primeira Constituição republicana não só mantivera esse princípio da descentralização da educação pública ${ }^{6}{ }^{6}$ contra o qual Rui Barbosa tanto se insurge - mas, indo mais longe, abolira a obrigatoriedade, eximindo, de uma só tacada, não só a sua responsabilidade, mas também a dos estados. Assim se prolongam as desigualdades e se induz à perpetuação, no dizer de Paschoal Lemme, de duas "organizações de ensino paralelas" (Lemme, 1961, p. 134) no país: uma delas, mantida pela iniciativa pública, incapaz de atender às exigências democratizadoras da república; e a outra, devido à iniciativa religiosa, inteiramente voltada para a formação das elites (Fernandes, 1966).

No entanto, talvez exatamente por tudo isso, o contexto em que Afrânio Peixoto celebra os "cem anos" do ensino primário seja também o próprio solo em que passa a se instituir, no país, a exigência tornada ainda mais urgente de educação pública comum, numa retomada de ideais e propostas presentes, ao menos formalmente, nas plataformas dos partidos políticos ${ }^{7} \mathrm{e}$

${ }^{6}$ Princípio que se apresenta como uma "evidência inquestionável do desinteresse republicano pela difusão da instrução": “A descentralização escolar, definida em 1834, foi reafirmada na Constituição de 1891, apesar das fartas e antigas denúncias, dos extensos diagnósticos e das estatísticas que revelavam o desastre que essa situação representara para o ensino elementar. Permaneceu como responsabilidade específica agora dos estados manter e legislar sobre a instrução pública elementar. [...] No novo contexto político, essa já tradicional divisão de competências no âmbito educacional mantinha-se em nome de princípios como o do federalismo e da autonomia dos estados. Sustentava-se, portanto, em princípios de que a oligarquia cafeeira lançara mão para não ter que arcar com o ônus das regiões pobres" (Xavier, Ribeiro \& Noronha, 1994, p. 105).

Assim, no Programa apresentado em 1913, pelo Partido Republicano Liberal, que tem autoria de Rui Barbosa: “Acreditando não haver inimigo maior da liberdade, no seio de um povo, do que a baixa do nível da sua inteligência e da sua cultura, o PRL vê, na reconstituição do ensino nacional, pela volta à seriedade e à solidez nos estudos, pelo desenvolvimento das capacidades e apti- nos movimentos ${ }^{8}$ em torno do evento republicano. Contexto que assiste à emergência das primeiras campanhas educacionais, que

[...] eram organizadas por políticos que, enquanto tais [sic], reconheciam a necessidade de difusão especialmente da escola primária como base da nacionalidade, o que fez com que alguns defendessem não só o combate ao analfabetismo, como também a introdução da formação patriótica, através do ensino cívico. (Ribeiro, 1995, p. 83)

Mas que assiste, também, à recrudescência do ímpeto reformador que, na área educacional, foi, a partir de 1922, responsável pelas mudanças que os estados realizam em seus sistemas de ensino.

A reafirmação da identidade republicana faz-se, no discurso de Afrânio Peixoto, retomada do ideal democrático que concede à educação seu caráter eminentemente político: trata-se de construir a unidade nacional, em nome de um projeto novo, ${ }^{10}$ de um governo "do povo, pelo povo e para o povo":

dões sob um regime contrário à vadiaria, à especulação e ao charlatanismo, uma das questões de atualidade mais grave e de mais viva urgência no problema de nossa regeneração" (Barbosa, 1946, p. 12).

${ }^{8}$ Desde a primeira década da República, as plataformas da Liga de Defesa Nacional e da Liga Nacionalista de São Paulo afirmam, enfaticamente, a importância política da educação pública na formação da Nação (Valle, 1996). Como destaca Marta de Carvalho (1989), a criação não só dessas Ligas, como também da Associação Brasileira de Educação evidenciarão, em seguida “[...] o desejo ardente de regenerar a Nação através da educação" (p. 4043).

${ }^{9}$ A partir de 1922, no Ceará (1922/25) e em São Paulo (1922/ 28); em 1925, no Rio Grande do Norte (1925/28); em 1927, no Paraná (1927/28), em Minas Gerais (1927/29) e no Distrito Federal (1927/30); na Bahia, em 1928.

${ }^{10}$ Em Pontos e bordados, J. M. de Carvalho analisa as imagens instituídas, ao longo do século XIX e até a primeira metade do século XX, na sociedade brasileira, destacando três imagens introduzidas pelas elites dominantes, para ressaltar que em nenhuma delas o povo toma parte: na primeira, ele está simplesmen- 
A instrução primária é o postulado da democracia, governo do povo, pelo povo e para o povo. Por isso, ela deve ser gratuita e obrigatória. É a condição mesma da existência de uma nação moderna. O seu primeiro caráter político deve ser, pois, "nacional". O nosso ideal é ter uma escola "única", disseminada, profusa, usinada "em série" da formação dos "mesmos" brasileiros, educados e cultos, e não, como agora, diversos pela alma e pela capacidade, isolados nos seus confinamentos regionais. (Peixoto, 1926, p. 519)

Assim, as lutas pela construção de uma unidade nacional que opuseram, ao longo de toda a Primeira República, os esforços de perpetuação dos poderes locais às iniciativas centralizadoras do Estado, concorrendo para a grande instabilidade política dos primeiros anos de República, travam-se agora, resolutamente, em terreno educacional. A exigência democrática de educação comum torna-se bandeira de luta na defesa dos privilégios da União ante a força das oligarquias instaladas, porque, sob o domínio dos Estados, “[...] a educação fundamental não pôde fazer brasileiros, mas cidadãos de pequenas 'pátrias' provincianas [...]". Peixoto (1926) completa:

Nestes trinta e tantos anos de regimen republicano, todos os nossos casuístas vêem querendo interpretar o texto da Constituição de 1891 para permitir a intervenção federal junto dos Estados parcos ou descuidados. É, pois, uma necessidade "nacional". (p. 19)

É claro, como já foi insistentemente mostrado, que essa defesa da unidade política está solidamente amparada na inédita influência que a burguesia industrial emergente ${ }^{11}$ passa a gozar no cenário político do país. Sob a égide, porém, do definitivo enraizamento liberal no Brasil, erguem-se as bases não só da face

te ausente; na segunda, ele é o elemento negativo e perturbador; na terceira, enfim, é um complemento valorizado pela visão paternalista de povo (1998, p. 233).

${ }^{11}$ Que levou alguns a refazer a história da educação brasileira à luz das periodizações oferecidas pela emergência do projeto urbano-industrial. Ver Ribeiro, 1995. nacional do capitalismo, mas do espaço público - que é também a perspectiva concreta para o questionamento de sua lógica de exclusão: por que a crítica do primeiro deveria conduzir à negação do segundo?

Ademais, até que ponto, e em que proveito, é possível fazer coincidir tão inteiramente toda defesa nacionalista e, mais especificamente, aquelas que respondem por ideais democráticos de ampliação das condições de acesso à educação e à cultura comuns, com a modelação liberal? Homem de convicções pouco habituais, o historiador José Murilo de Carvalho acredita haver sido, não a República Velha, mas a Monarquia a instituir as bases essenciais do liberalismo no país:

No que se refere aos princípios ordenadores da ordem social e política, o liberalismo já havia sido implantado pelo regime imperial em quase toda sua extensão. A Lei das Terras de 1850 liberara a propriedade rural na medida em que regulara seu registro e promovera sua venda como mecanismo de levantamento de recursos para a importação de mão-de-obra. A Lei das Sociedades Anônimas de 1882 liberara o capital, eliminando restrições à incorporação das empresas. A abolição da escravidão liberara o trabalho. A liberdade de manifestação de pensamento, de reunião, de profissão, a garantia de propriedade, tudo isso era parte da Constituição de 1824. No que se refere aos direitos civis, pouco foi acrescentado pela Constituição de 1891. (J.M. de Carvalho, 1989, p. 43)

Restaria, e é evidente que J. M. de Carvalho finge desconhecê-lo, que as exigências de uma economia agrário-exportadora não são as mesmas de uma economia que se pretende urbano-industrial. Mas a organização da atividade econômica setorizada, muito mais do que a unificação do mercado interno, impõe as regras e exigências do tipo de desenvolvimento imposto ao país. Nesse sentido, a ampliação da escolarização, como já Rui Barbosa percebera, apresenta-se como necessidade de difusão de valores essenciais para o progresso da nova ordem social, além de habilidades mínimas de leitura e escrita. Liberal, Rui talvez seja um dos primeiros a defender a tese 
segundo a qual a melhoria das condições educacionais implica, diretamente, aumento de produtividade para a sociedade - tese que o estadista recebe, aliás, dos construtores da "democracia econômica" americana que tanto admira. O que propõe não é, porém, uma "educação técnica" generalizada ao povo nas escolas comuns, mas antes uma "instrução suficiente para ler, compreender e pensar" (Barbosa, 1947). ${ }^{12}$ No entanto, seria impossível reduzir sua defesa da educação pública aos argumentos da lógica econômica. Ao contrário, citando John Stuart Mill, Rui Barbosa imprime à limpidez da doutrina da mínima intervenção e da auto-regulação os limites da construção pública:

É, portanto, a educação uma das coisas que, podemolo admitir como princípio, o governo deve distribuir ao povo. Ela constitui um dos casos a que não se aplicam necessariamente os motivos da regra de não intervenção, e a que nem todos esses motivos são aplicáveis. (Mill apud Barbosa, 1947, p. 107)

Destoando, portanto, da boa-fé liberal em relação à constituição espontaneamente equilibrada do mercado, Rui fazia da obrigatoriedade escolar a conseqüência direta do raciocínio inverso: o do direito do Estado $^{13}$ de reclamar a si a responsabilidade de defesa da Nação contra ela própria. Para ele, o Estado liberal que deveria "proteger os indivíduos e proprie-

\footnotetext{
12 "Não é que atribuamos à instrução elementar a proprieda-
} de mágica de eliminar diretamente a imoralidade de cada espírito, de onde elimine a ignorância. Mas, além de que nada tende mais a inspirar o sentimento da ordem, o amor do bem e a submissão às amargas necessidades da vida do que a noção clara das grandes leis naturais que regem o universo e a sociedade, acresce que o ensino desentranha, em cada um dos indivíduos cuja inteligência desenvolve, forças de produção, elementos de riqueza, energias morais e aptidões práticas de invenção e aplicação, que o revestem de meios para a luta da existência, o endurecem contra as dificuldades e lhe preparam probabilidades mais seguras contra a má fortuna" (Barbosa, 1947, p. 195, grifos nossos).

13 "O divisor de águas encontra-se em 1915, a partir de quando se caminhou [...]" no sentido de alguma unificação. Enquanto dades" contra os excessos pontuais que pudessem ser cometidos necessitaria também, tal qual somente o rousseaunianismo francês pudera conceber, resguardar o país contra os vícios que ele próprio carregava: a ignorância, a irracionalidade, a desordem, tanto quanto a tirania.

\section{Perspectivas democráticas num estado forte}

Os republicanos radicais talvez tivessem sido os únicos a propor uma idéia da pátria compatível com a cidadania liberal e democrática, descontados os traços rousseaunianos que a tingiam. Mas, ao evoluir para o nativismo exacerbado do movimento jacobino e para o autoritarismo florianista, a proposta radical perdeu viabilidade política [...] O nacionalismo xenófobo seria apropriado pela elite exatamente para combater a militância operária, dando razão aos anarquistas quando diziam que pátria era só para os exploradores. [...] De um lado, o liberalismo era utilizado pelos vitoriosos como instrumento de consolidação do poder, desvinculado da preocupação de ampliação das bases deste poder. De outro, as demandas de ampliação foram formuladas, na maior parte, seja dentro da perspectiva integradora do positivismo, seja dentro da fuga romântica do anarquismo e do radicalismo republicano de estilo rousseauniano. Balançava-se entre a negação da participação, a participação autoritária e a alienação. (J. M. de Carvalho, 1989, p. 63-64)

O conhecido e pessimista diagnóstico de José Murilo de Carvalho dispõe, no horizonte da construção política brasileira, alternativas bastante sombrias no que respeita ao ideal democrático de participação ampliada nas decisões. A constituição de um Estado forte - que, acrescentemos, imprimiu historicamente en-

Rivadávia Corrêa pretendia "eliminar de todo a intervenção do Estado nas coisas do ensino", João Luís Alves defendia a colaboração do governo federal com os estaduais, em 1925, partindo de que "autonomia não é independência nem soberania" e sim "liberdade de ação sob uma superintendência orgânica" (Chagas, 1978, p. 26). 
tre nós uma nova acepção para a velha prática de privatização do poder (Valle, 1996) - estaria na base da formação histórica de um cidadão inexoravelmente passivo, tipo antropológico definitivo, a marcar os rígidos limites à democratização da sociedade brasileira.

Não há dúvida de que a construção da sociedade brasileira cedeu muito pouco, ou quase nada, às expectativas mais democráticas (J. M. de Carvalho, 1989, p. 35) de universalização da participação política; tanto quanto é evidente que sua tíbia afirmação, em nosso país - que sempre encontrou na educação um dos terrenos privilegiados de enunciação -, está eivada das ambigüidades que tecem as disputas de poder entre segmentos da elite dominante. No entanto, seria um esforço de todo vazio buscar entender essas ambigüidades? Deveria a tentativa ceder lugar, pela simples contabilidade dos resultados históricos, à desconsideração das polêmicas educacionais, resumidamente elencadas na categoria de idiossincrasias das elites dominantes? Por que essas idiossincrasias conduziriam, justamente, aos argumentos democráticos, e não a outros? Sendo esses argumentos tão pouco capazes de efetiva instituição - de encarnação na sociedade, sob a forma de expectativas, de razões de ser, de bandeiras de luta -, então por que ainda defender a democracia, e sob as bases de que espécie de legitimação?

No entanto, a instituição dos valores democráticos, ainda que frágil e sempre provisória, não se dá, pelo menos entre nós - se é que, em algum contexto isso foi diferente -, com o purismo e a clareza que as leituras de nosso passado parecem reivindicar. Ela deve ser buscada nos desvãos de uma história de dominação, como frestas que o valor democrático, feito anseio de universalização da instrução pelas mais diferentes razões, investiu.

A defesa da educação pública reuniu, nas primeiras décadas do século, militantes dos mais diferentes matizes contra a idéia de uma federação independente de oligarquias locais: o princípio democrático de universalização da escola unificou os descontentamentos esparsos em uma única bandeira - a da intervenção ativa do Estado e, para fazê-lo, teve de se indispor ainda contra outras formas de autoridade que, resis- tindo à autoridade nacional, amparavam o poder tradicional. Eram elas, basicamente, a religião e a família, duas forças em que o patrimonialismo decerto se apoiava e que estarão, ainda e por um longo tempo, colocadas a serviço da manutenção do status quo das estruturas tradicionais de poder.

Por isso, não é por acaso que, lamentando o "grande erro da sua descentralização", que corta a história brasileira desde o estabelecimento das primeiras leis de ensino no país, após a Independência, até a República, Aleixo Vasconcellos vai apoiar-se no modelo espartano - grande quimera jacobina que alimentara, na França, os ideais revolucionários e a emergência das exigências democráticas da educação - recuperado em nome da expansão da autoridade do Estado não só sobre os poderes locais, mas inclusive sobre a autoridade familiar: é "boa doutrina na questão da instrução popular" - não é ele quem o diz, são os antigos! - que ao Estado caiba, de modo absoluto, a educação das crianças. $\mathrm{O}$ cômodo distanciamento que o passado introduz talvez seja a grande razão que leva o autor a apelar para o sentido político da educação na Antigüidade, ainda que de forma destorcida, e ao preço do forte anacronismo que permite apelidar de "Estado" algo que de fato corresponderia muito pouco à prática de monopolização das decisões sugerida. Em seus sonhos, na democracia antiga,

Os pais não devem ter a liberdade de deliberar sobre a ida dos filhos à casa do mestre que a criança escolheu. As crianças pertencem menos aos pais que às cidades. $\mathrm{O}$ corpo e a alma de cada cidadão são propriedades do Estado; por isso, ele os prepara de modo a obter o melhor partido. Ensina-se a ginástica, porque o corpo do homem é uma arma para a cidade. Ensinam-se hinos, cânticos religiosos e danças sagradas para a boa execução dos sacrifícios e das festas da cidade. (Vasconcellos, 1922, p. 6)

Mas é claro que esses excessos estão longe de

${ }^{14}$ Expressas pelo mandonismo, coronelismo e clientelismo (J. M. de Carvalho, 1998, p. 130). 
desfrutar de qualquer unanimidade, mesmo entre os defensores da instrução pública. Eles são, em especial, objeto da crítica mais virulenta e mais enfática dos tradicionalistas, em nome da liberdade de ensino que, nesse momento da história da educação pública brasileira, é vigorosamente empunhada pelos católicos. ${ }^{15}$ Para estes, a autoridade paterna - sede e metáfora, desde o direito romano, da privatização do poder - é um princípio inabalável; a menos que se tratem de "pais incapazes, descuidados e perversos", é "inviolável" o poder "físico, intelectual, moral e religioso" que as famílias devem exercer sobre seus membros:

[...] ao Estado se impõe o dever de não violentar a consciência dos cidadãos. Tratando-se de crianças confiadas às suas escolas, incumbe-lhe a mais estrita obrigação de respeitar as convicções religiosas das famílias, desde que não se achem em oposição com as exigências da moralidade pública expressas no Código penal. A criança não pertence ao Estado; aos pais, incumbe o dever e assiste o direito de lhe ministrar a educação física, intelectual, moral e religiosa a que tem direito inviolável. E se é justa uma legislação quando defende os interesses da prole contra os pais incapazes, descuidados ou perversos, não é o menos quando, contra terceiros que a viessem embaraçar, tutela e ação eficaz das famílias normalmente constituídas. A escola

15 “O ajustamento à nova ordem social não foi traumático para os católicos brasileiros, como acontecera em outros países. Implantado o novo regime, a acirrada batalha entre católicos e liberais e entre católicos e positivistas ou maçons vai cessando de maneira progressiva. Poucas são as vozes que acenam com um retorno à situação anterior. Para alguns, terminara a época de desprestígio da Igreja Católica, tão acentuado durante a Monarquia, com a instituição do Regalismo. Para estes, não se admitia qualquer pretexto para o pessimismo: 'estamos no regime do direito comum; devemos aproveitar a liberdade que nos é dada'. Afora um ou outro acontecimento que não chegaram definir uma 'questão religiosa', os dois primeiros decênios do regime republicano devem ser caracterizados como de calmaria nos meios católicos brasileiros. Apenas durante a terceira década se esboçam as primeiras manifestações mais importantes que eclodirão no decênio seguinte, sob a forma de chamamento geral" (Nagle, 1974, p. 57). continuadora da primeira formação é o complemento do lar; deve prolongar-lhe a obra educadora, não destruí-la ou embaraçá-la. O professor, público ou particular, é, por função, um delegado e representante da autoridade paterna. Não lhe assistem direitos contra o direito das famílias. (Franca, 1931, p. 60-61)

Mas quem estabelecerá os limites de definição dessa autoridade familiar "incapaz, descuidada e perversa"? No que consistem a incapacidade, o descuido e a perversidade em nome das quais se poderia, legitimamente, libertar o indivíduo da tutela exclusiva de seu meio familiar, e quem poderia em toda legitimidade reivindicá-lo? Parece evidente que, na falta de uma explicitação maior, são os princípios da boa moral cristã que separarão ainda a sociedade dos proprietários de bens e valores morais dos em tudo desafortunados.

Curioso é que tenha havido aqueles que, em nome dos mesmos ideais da religião e do apego às tradições, propugnassem pela intervenção do Estado, como é o caso de Ennes de Souza, deputado ainda durante o governo Floriano Peixoto. Para o parlamentar, uma das funções precípuas do Estado consiste - como pretendia o autoritarismo iluminista, em defender a sociedade contra ela mesma, reprimir o mal e, ao mesmo tempo, difundir as luzes:

Impedir a violência, a opressão, o ultraje, proteger a vida dos cidadãos, os seus bens, a sua honra, o legítimo exercício de todos os seus direitos, é reprimir o mal. Mas o Estado não deve limitar-se a reprimir o mal; esta missão será superior às suas forças, se ao mesmo tempo não concorrer energicamente para a realização do bem, se não auxiliar o cidadão no cumprimento dos deveres deste, se não colocar ao alcance dele os meios de desenvolver as suas faculdades e atingir o alvo da sua existência. Efetivamente, baldados são todos os esforços para impedir ou sufocar o mal, quando o mal tem a raiz, a sua causa permanente, no coração da sociedade. É o que sucede quando a maioria da nação permanece abismada na ignorância, pela falta de meios de instrução; no embrutecimento, pela falta de educação e influência moral; na miséria, por ignorar os recur- 
sos e os interesses do país, por menosprezar as artes que alimentam e enriquecem um povo, nobilitando-o pelo trabalho. É preciso que ele distribua por todas as classes da sociedade, segundo as aptidões e as necessidades de cada qual, o alimento da inteligência. É necessário que lhes assegure uma educação, própria para lhes estimular não só o amor do bem, mas o hábito dele, o culto da pátria e da família, e, mais que tudo, estas santas crenças em uma providência e uma justiça divina, que, debaixo das diversas formas que a liberdade de consciência reclama, são, a um tempo, a glória, a força e a consolação do gênero humano. (Franck, 1893, p. 77-78)

Imbuído dessa tarefa de proteger a sociedade contra ela mesma, o Estado edifica-se como autoridade final, representante exclusivo dos anseios comuns, em nome dos quais se deve limitar todo tipo de influência que lhes resista. Sem a perspectiva da participação ampliada, os valores comuns servem, assim, de fundamento para a monopolização do poder - tal como a "Monarquia iluminada" de Pedro II o havia concebido, tal como a tirania sempre o concebe. Há, porém, que reconhecer, na construção dessa "soberania razoável" e todo iluminista, na emergência da figura nada liberal de um "direito da Nação" - entenda-se, do direito do Estado de falar em nome da coletividade para exigir de cada um dos indivíduos o que é indispensável ao bem comum - as verdadeiras bases do que, entre nós, poderia ser denominado espaço público.

Com essa propriedade singular que caracteriza a ignorância, de perpetuar-se a si mesma, a soberania do pai ignorante degenerará na mais cruel das tiranias. É a tirania, não a soberania razoável, que o ensino obrigatório combate.

[...] A lei a que se filia, portanto, esse encargo público assumido pelo país, não é facilitar à paternidade o exercício de um múnus doméstico ante cuja infração a autoridade se reconheça desarmada. Esse compromisso com que a constituição grava o orçamento público, exprime dois direitos, que têm sua sanção na comunidade organizada politicamente: o direito, irrecusável a toda criatura humana, de que a sociedade lhe subministre, no primeiro período da evolução individual, os princípios elementares de moralidade e de intelectualidade, sem os quais não há homem responsável, sem os quais é cativeiro a lei, absurdo a imputabilidade e a repressão injustiça; e, a par desse direito do indivíduo para com a coletividade social, o direito correlativo, incontestável a esta, de negar à ignorância do indivíduo a liberdade de obrigar a nação a receber do seio da ordem comum cérebros atrofiados pela ausência dessa educação rudimentar, e à míngua da qual o ente humano se desnatura, e inabilita para a convivência racional. (Franck, 1893, p. 198, 183)

Mas a obrigatoriedade da educação comum se apresenta, nessas circunstâncias, como uma bandeira capaz de reunir as mais díspares posições em torno de uma mesma fé nos benefícios "intrínsecos" da iluminação das razões. Para o "jacobinismo" republicano, tanto quanto para o liberalismo conseqüente, não há direito à ignorância, não há benefício algum na manutenção da dominação surda: os pilares do patriarcalismo devem vergar-se diante da urgência de uma sólida adesão, que envolva um convencimento que a educação é capaz de operar. É essa, para começar, a ambigüidade que a defesa da educação impõe, mesmo quando, por força de sua generalidade, os princípios democráticos inclinam-se tão disciplinadamente às aspirações dominadoras da classe emergente:

Se, no seio de outras nações, a obrigatoriedade foi um expediente seguro, entre nós ela assumia o caráter de uma necessidade iniludível, de satisfação inadiável; pois, se entre povos de iniciativa e estímulos tal medida foi aos olhos dos governos urgentíssima, tratando-se dos nossos patrícios, baldos dessas qualidades, (é preciso confessá-lo), ela se impunha como remédio de resultados eficazes. Pretender, acastelado nos princípios da democracia e nos conceitos da liberdade individual, combater a obrigatoriedade

${ }^{16}$ O jornal O Paiz, em sua edição de 3/5/1894, anunciava a inauguração do periódico O Jacobino, que expressava em seu programa a defesa intransigente da instrução pública obrigatória. Deocleciano Mártir, que responde pelo artigo publicado no jornal citado, declara que "O Jacobino propõe-se a defender com altruísmo todas as causas que se referem ao Povo, ao Brasil e à República”. 
do ensino primário é defender a ignorância das massas, que tantos males acarreta, prejudicando-lhes o bem estar futuro, o progresso do país e o seu desenvolvimento; é dizer ao povo: "vós não compreendeis as vantagens da educação, tendes natural aversão à escola, por isso mesmo que não lhe medis o alcance; pois bem, não vades à escola, porque sois livre, porque sois cidadãos, porque ninguém poderá obrigar-vos a freqüentá-la; permanecei ignorantes e estais no vosso direito!" Mas não são lógicos os adversários da obrigatoriedade, pois, se o fossem, deveriam levar a defesa da liberdade individual às suas últimas consequiências, [...] clamar contra as leis que impõem pesados impostos, contra disposições municipais que proíbem ou restringem muitos atos dos cidadãos na sociedade; que se revoltem contra a moral que nos obriga a guardar o respeito e o decoro públicos e a polícia que proíbe, muitas vezes, até certos excessos, só prejudiciais a quem os pratica. (Costa, 1907, p. 18)

Mas quem recusará, às palavras então proferidas, o selo da adesão? O nacionalismo da época defende, talvez, um ideal cuja amplitude desconheça e cujas consequiências, se conhecesse, seguramente abominaria.

O problema maior, a nosso ver, não está aí, senão naquilo que nenhuma crítica ao caráter "liberal" da escola pública foi capaz de expor: a instituição da noção de que a participação política deveria ser uma consequiência do acesso à educação, e não a principal causa para a sua defesa. É esse o verdadeiro ponto de contato entre as mais diferentes concepções educacionais, que têm em comum o princípio, formal ou efetivamente defendido, de que é o acesso ao patrimônio escolar que legitima a reivindicação de igualdade política, e não o contrário:

Para ganhar a vida, para ser bom cidadão, o homem precisa ser instruído. Nenhuma profissão, por mais modesta que seja, pode dispensar a instrução. Quanto maior e mais aperfeiçoada for a instrução, mais facilmente se logrará alcançar o que se deseja, melhor se poderá servir à Pátria. O homem só é verdadeiramente livre quando é instruído, porque, do contrário, estará sempre na dependência de outrem. (Araújo Castro, 1928, p. 44-45)

\section{Participação política e instrução na cidadania moderna}

Buscando na tradição política brasileira as evidências de uma "ética individualista associativa", J. M. de Carvalho (1989, p. 151-152) vai ser obrigado a concluir, como já afirmamos, pela inexistência de qualquer sustentação para uma cidadania ativa. No liberalismo à brasileira, o individualismo exacerbado descuraria de qualquer exigência de associação; no âmbito dos ideais integradores e comunitaristas do positivismo e do "republicanismo rousseauniano", a iniciativa individual se desfaria à sombra de um Estado forte.

A concepção restritiva de participação era fundamentada, segundo o autor, em uma distinção nítida entre sociedade civil e sociedade política, introduzida pela Constituição monárquica de 1824, que estabelecia a diferença entre os cidadãos "ativos", a quem eram atribuídos "direitos políticos", e cidadãos "passivos", para os quais só se reconheciam os "direitos civis". Mas é evidente que, nesse contexto, a participação política só poderia aparecer como uma concessão pessoal e sempre provisória do soberano àqueles que, súditos, distinguem-se por sua colaboração. Nesse sentido, é a integralidade da lógica monárquica que, por detrás de seu glossário de neologismos, resiste a qualquer análise: como significar coerentemente palavras como "cidadão", "direitos", "atividade", "sociedade política" e "sociedade civil" a partir dessa lógica?

Deve-se supor, então, que não é uma concepção de participação, mas do seu contrário, de monopolização do poder que não é rompida com o advento da República. Assim, afirmando, pela reedição do censo eleitoral, agora fixado apenas na condição de alfabetização, uma concepção "dualista" de cidadania, a constituição republicana decerto não faria figura de exceção entre as demais nações ${ }^{17}$ - não houvesse ela,

${ }^{17}$ Como, por exemplo, a Inglaterra, onde até a década de 1860 somente as classes proprietárias votaram. Nos demais países europeus, a situação não era muito diferente, ao menos até as décadas de 1870-1880. Para uma análise mais detalhada, cf. Hobsbawm (1996, 1988); sobre a reforma eleitoral inglesa de 1832, 
concomitantemente, negado a responsabilidade do Estado em oferecer, pela instrução pública, uma perspectiva de inclusão dos analfabetos. Mais ainda, considerando-se que somente os brasileiros mais abonados teriam condições de arcar com os custos da educação privada, a exclusão dos analfabetos não é somente altamente discriminatória como reintroduz, subrepticiamente, a condição econômica que havia formalmente superado.

Porém, mais do que tudo, a vitória do princípio "federativo" e do fortalecimento dos poderes locais já tinge, por si só, a noção de cidadania republicana das cores da farsa, servindo para reafirmar as tiranias regionais. Por isso, se a mudança de regime político legitimamente despertou, em vários setores da população, a expectativa de expansão dos direitos políticos, os espaços concretos para essa ampliação não estavam dados, e seria ainda preciso instituí-los na própria lógica republicana. Compactuando com as exclusões que a ordem patrimonialista sempre realizara, ela afastava-se radicalmente, no primeiro momento, de qualquer possibilidade de democratização.

Nas primeiras décadas do século XX, o fortalecimento do projeto de construção nacional traz à tona a exigência de instituição ampliada dos modelos de cidadania cuja concretização será, de forma sistemática, atribuída à escola pública. Mas, se a área da educação é espaço para a enunciação das exigências democráticas, ela também é o lugar em que as resistências à sua realização vão se evidenciar. Ainda que tanto umas como outras possam tomar, nos discursos, formas extremas, parece-nos ser para o tipo antropológico do homem das luzes que as posições vão convergir.

O caráter político que passa a ser associado à escola é o de fiadora das condições de realização do projeto democrático: a educação comum é cada vez mais investida da tarefa de afastar definitivamente os entraves que se opõem à solidificação da realidade republicana.

Thompson (1987); e, para um estudo comparativo das reformas eleitorais na Europa Ocidental, na metade final do século XIX, Hirschman (1992).
No campo educacional, a noção de educação como "panacéia" foi exaustivamente criticada (para não citar mais do que dois exemplos, cf. Nagle, 1974; Paiva, 1973) e, de certa forma, anatematizada pela crítica das teorias que, a partir dos anos de 1970, não aceitavam creditar à escola mais do que o papel de reprodutora das desigualdades sociais. Mas não seria excessivo afirmar que nem sob a influência poderosa do mito oposto - o do total impoder da educação tenha-se de fato superado a concepção de uma educação magicamente demiúrgica.

No que consistiria, de fato, o caráter "mágico" da valorização da educação? Por certo, a crença de que a ação isolada da escola é suficiente para produzir as determinações sociais consideradas é inadmissível - tanto, aliás, quanto a crença de que uma atividade social de formação de indivíduos possa ser inteira e exaustivamente congruente com a ideologia do controle, até o ponto da total insubstancialidade de qualquer outra dimensão. A questão merece, portanto, ser analisada com mais cuidado. O princípio que estava na base do "entusiasmo" pela educação não era, sem dúvida, o de que a sociedade poderia cruzar os braços, deixando a cargo da escola a concretização de todas as suas exigências políticas, mas antes o de que a educação consistia no pré-requisito indispensável para a concretização legal e institucional dessas exigências.

Depositária de precondições sem as quais, afirmava-se, o sonho democrático tornar-se-ia inexoravelmente em pesadelo, a escola foi feita, historicamente, o melhor argumento de legitimação das contradições da ordem liberal: permitindo a reafirmação constante de um ideal convenientemente postergado, ela era, ademais, álibi para a dominação social, tanto quanto para a desqualificação popular. No entanto, não seria lícito supor que essa perspectiva cínica era compartilhada pela integralidade daqueles que depositaram suas esperanças na escola, longe de lá - tal como não é correto atribuir a totalidade dos ideais educacionais da época ao projeto de Estado autoritário a partir daí posto em prática no país.

Mais correto é afirmar que o que se comparti- 
lhou, então, mantém-se até hoje correntemente em uso, nas mais diferentes posições políticas: a viciosa associação entre a participação política e instrução, instalada desde a "sociedade educativa" de Platão como legitimação da idéia de que há, nas sociedades, "especialistas" do poder, ${ }^{18}$ e que a esses devem ser confiadas as deliberações comuns. Platão insurgia-se contra a prática democrática de seu tempo - caracterizada, exatamente, pela afirmação de que a política era um domínio que igualava os indivíduos, não requerendo qualquer tipo de habilidade específica. Tal como o racionalismo platônico, sua versão moderna pretendeu subverter o princípio de igualdade política que é essencialmente constitutivo do projeto democrático. Assim, a igualdade política já não é ponto de partida do qual decorrem não só a prática de deliberação como o acesso à paideía comum: ela é uma condição imposta à democracia, pela qual se admite - o que Rousseau não se cansou de contestar - que é pela ciência e pelo saber que se chega à virtude social.

Não se trata, é claro, de negar que a política é espaço de deliberação racional e da reflexão, nem a contribuição específica da educação na edificação do espaço público. Porém, a igualdade política não pode ser fundada senão no respeito incondicional à autonomia de cada indivíduo. É essa lição essencial da democracia que é inteiramente distorcida, sob pretexto da exigência de instrução. A “cidadania universal” passa a ter um preço: a universalização dos valores que permitem assegurar que ela não vá conduzir para longe dos resultados que se acredita "naturalmente" universais.

Embora, formalmente, todos sejam cidadãos, só é cidadão, nas “democracias modernas”, aquele que é

\footnotetext{
${ }^{18}$ Em favor de Platão, é ainda preciso acrescentar que, para o filósofo, estes "especialistas" não se confundiam, como atualmente, com os profissionais da política, economistas, homens de partido. Ao invés de se identificarem com o poder econômico, na concepção platônica os filósofos não possuiriam bens privados, tanto quanto não contrairiam matrimônio, não se consagrando a nenhuma destas atividades que dominam a construção da existência privada. Ainda sobre a questão, cf. Castoriadis, 2000, p. 34.
}

instruído. Mais ainda, a equivalência entre instrução e cidadania acaba por definir a própria humanidade: sem a instrução, está-se excluído não só da sociedade, mas da própria espécie. Não é o que afirmam incessantemente os discursos educacionais?

[...] a ninguém preocupa a decadência da instrução primária, a completa ausência da educação popular, esquecidos todos nós de que, se a instrução superior prepara as altas camadas sociais, desenvolve a ciência e habilita o homem a escravizar, cada vez mais, a natureza; se a secundária, desenvolvendo o espirito da mocidade, a torna capaz de outros conhecimentos úteis e proveitosos, preparando-a para a vida na sociedade moderna; a primária conduz ao cérebro humano os primeiros raios dessa luz preciosíssima que faz germinar a semente de todos os progressos, fornecendo aos povos a base de conhecimentos indispensáveis, “[...] sem os quais o indivíduo não é nem homem nem cidadão"; esquecidos todos nós de que esta é a que precisamos derramar por todas as camadas populares, porque só ela é acessível à maioria da nação. (Costa, 1907, p. 7, com nossos grifos)

Na curiosa conversão que a modernidade acaba por operar sobre a noção de autonomia, o que era inicialmente característica inalienável do indivíduo humano passa a ser uma possibilidade engendrada pelo progresso da sociedade; ao mesmo tempo que sua expressão já não é eminentemente política e pública, mas refere-se principalmente a atributos individuais e subjetivos:

[...] a originalidade pedagógica do movimento iluminista não consiste somente no novo conceito de educação, mas também no novo fim a ser alcançado que não é mais a sapiens et eloquens pietas ou a literata pietas do Humanismo confessional, quer católico quer protestante, mas sim a formação do cidadão, o qual, mediante o saber, se deve elevar a autonomia intelectual e moral até mesmo [sic] política. (Quaglio, 1931, p. 2)

Como evitar de ver nessa "autonomia intelectual e moral" o seu contrário, isso é, a sujeição a valores 
que permitem assegurar antecipadamente o resultado da deliberação? Como entender, sob essas bases, o direito à educação?

O primeiro dever pois, de cada cidadão de cada pátria é instruir-se e instruir; o primeiro dever de todos os governos de todos os Estados é proporcionar, cada vez melhormente, o desenvolvimento da instrução do povo. (Cardoso, 1926, p. 17-18)

Se há dever do Estado de prover a educação pública, ele é correlativo ao dever de cada cidadão de buscar essa instrução; porém, dos dois deveres, apenas aquele que obriga o indivíduo volta-se em direito, a qualquer momento reivindicado pelo Estado, como justificativa para as exclusões que opera.

Como já dissemos desde o primeiro momento, o princípio da obrigatoriedade em que se apóia a idéia da educação pública se introduz como limitação do reconhecimento da autoridade do pater familias. Aparece, porém, nos discursos educacionais, uma versão na qual o objetivo maior não é, como em outros contextos, o de criação de uma uniformidade social entre as classes sociais que, para além da tutela familiar, apenas o Estado pode fomentar, mas o da prevenção ativa dos prejuízos que a "natural aversão" ou ignorância das classes desprivilegiadas pode acarretar para toda a sociedade:

Se o pai não educa os filhos, se não compreende as vantagens da instrução elementar, dos conhecimentos que a escola proporciona para serem bons cidadãos e homens úteis, o Governo que os arranque da indolência para os mandar às aulas publicas. [...] $\mathrm{O}$ pai, o tutor, o parente têm o direito de dar a seu filho ou tutelado a profissão que bem lhes convier, depois de ter cursado a criança, por algum tempo, a aula primária, onde deve ter aprendido a ler e escrever, encontrando ali a sua inteligência a compreensão de tanta coisa útil e indispensável; segregá-lo, porém, da escola, para enviá-lo logo à tenda do sapateiro é desumano e cruel! (Costa, 1907, p. 23)

Instalada como pré-requisito para afirmação de um princípio político, a educação cumpre uma rotina inteiramente oposta a que, inicialmente, parece supor: a insistência em fazê-la instrumento de conversão das diferenças na igualdade política encobre a manutenção concreta das injustiças sociais e a intenção de controle ampliado da sociedade:

Cada indivíduo, elevado à categoria de cidadão, é apto para o exercício dos direitos políticos - mercê da capacidade que para isso lhe proporciona a instrução, mesmo em grau elementar - poderá melhor compreender a extensão dos seus direitos e avaliar até onde lhe chegam os deveres correlativos. [...] o cidadão consciente será necessariamente um elemento de ordem e fator de bem estar coletivo. (Costa, 1907, p. 95 , com nossos grifos)

O mesmo autor citado, Afonso Costa, afirmava ainda, no início do século, a crença de que só a educação poderia despertar nos brasileiros “[...] um entusiasmo de amor esclarecido, que estuda, que raciocina, que pondera, e busca exatamente nas lições da história descobrir quais os nossos legítimos interesses [...]". Em particular, a liberdade que o esclarecimento provê resulta do claro conhecimento dos limites de sua competência:

O patriotismo verdadeiro [...] não é amor cego [...] Ao contrário. O cidadão prestante, reconhecendo os erros, as deficiências, as necessidades de sua Pátria, esforça-se, na esfera de sua influência, por corrigir ou minorar tais males. (Costa, 1907, p. 61, nossos grifos)

Da educação que é condição para a participação pode-se, ademais, implicar todas as "virtudes políticas” e, para começar, aquelas necessárias à preservação da ordem social, ${ }^{19}$ como faz entender, na mesma

\footnotetext{
${ }^{19}$ No início do século XX, uma cartilha destinada a crianças resumia os deveres e os direitos do cidadão, estes últimos divididos em direitos "civis" e "políticos": "Os primeiros deveres civis são: respeito às leis e obediência às autoridades; defesa Nacional e dever de bem servir à Pátria; prevenir, impedir e reprimir a desordem, que é sempre nociva à liberdade; procurar o melhoramento
} 
época, José Feliciano, para quem “ser bom cidadão é a maneira mais decisiva de ser um bom homem, um homem social", que do civismo espera a própria "consolidação dos liames domésticos":

A urbanidade lhes ensinará [aos futuros cidadãos] a respeitar melhor as autoridades que personificam a ordem social, e os fará poupar os haveres humanos, hoje dilapidados como se foram ganho individual de seus pródigos apreensores. O governo constituído é sempre uma força respeitável, embora subjetivamente, moralmente haja governados superiores aos governantes. Sem servilismo, por urbanidade social, todos devem respeitá-lo, sem críticas irritantes, sem comparações irracionais com modelos problemáticos ou com tipos ideais. Este respeito deve estenderse às dignas forças econômicas, aos capitalistas, hoje tão atacados pelos espíritos destruidores. As forças sociais, assim consolidadas, enobrecidas, livres dos cuidados absorventes de uma defesa contínua, frutificarão em resultados verdadeiramente progressivos. (Feliciano, 1903, p. 31-32)

Implicam-se, inicialmente, os valores patrióticos em nome dos quais o trabalho é valorizado, e em relação aos quais a cidadania é definida como desenvolvimento individual de habilidades morais, intelectuais e profissionais que convergirão para o progresso nacional. ${ }^{20}$ A participação a que a cidadania dá acesso depende da adesão a um patrimônio de valores que, somente eles, poderão atribuir à contribuição individual sua implicação coletiva:

moral, econômico e civil do Estado. Os direitos dividem-se em civis e políticos. Os civis são: gozar da liberdade; garantia da pessoa, honra e propriedade; os políticos são: direito eleitoral; direito de elegibilidade; direito de ser jurado; direito de petição" (Capri, 1909, p. 31-39).

${ }^{20}$ "O que o cidadão deve saber" - manual que Sampaio Dória elabora para a Liga Nacionalista - registra as leis do "decálogo" cívico: "1- Amar a liberdade; 2- Defender a pátria; 3- Pagar impostos; 4- Votar; 5- Cooperar na política; 6- Servir no Juri; 7Respeitar a lei; 8- Fiscalizar; 9- Falar bem a sua língua; 10- Não desdenhar a civilidade” (Sampaio Dória, 1923, p. 193-194).
Sejamos, portanto, patriotas, para que possamos ser bons cidadãos. Estudemos, eduquemos nosso espírito, cultivemos o nosso intelecto, desenvolvamos a nossa indústria, o nosso comércio, a nossa agricultura; sejamos trabalhadores e ativos, para fazermos do Brasil uma nação culta e elevada, a primeira potência da América do Sul. (Cunha Avellar \& Avellar, 1915, p. 12)

Porém, as transformações por que passa o país cedo exigem, e cada vez mais, a reconversão dessa adesão espiritual em termos de uma operosidade funcional. Das exigências de instituição do capitalismo, entre nós como em toda parte, resultou a identificação irrestrita da cidadania com a participação no trabalho.

Soou, afinal, para o Brasil a hora da construção econômica. Consolidado politicamente o país, o que se pode julgar realizado com a estabilidade da República, o problema é não já de construção da nacionalidade, no ponto de vista político, mas de consolidação nacional no ponto de vista econômico. Existe o cidadão, é porém preciso que nele subsista também o trabalhador, o fator direto da vida nacional e o impulsionador da evolução da pátria. (Carneiro Leão, 1918 , p. 5)

Essa assimilação da cidadania ao trabalho tem vantagens educacionais evidentes: pois, à luz desse trabalhador abstrato que se trata agora de formar, tornam-se cada vez mais genéricos e formais os termos pelos quais se pensa, na Escola pública, a formação do cidadão.

LÍLIAN DO VALLE, doutora em educação pela Universidade de Paris V (1982), é professora titular de filosofia da educação da UERJ e autora, entre outros, de A escola e a nação (Letras \& Letras, 1996), A escola imaginária (DPA, 1997) e Enigmas da aprendizagem (no prelo).

\section{Referências Bibliográficas}

ARAÚJO CASTRO, (1928). Instrução moral, cívica e social. Rio de Janeiro: Livraria Editora Freitas Bastos. 
AZEVEDO, Fernando de, (1963). A cultura brasileira. $4^{\mathrm{a}}$ ed. Brasília: Ed. UnB

BARBOSA, Rui, (1947). Reforma do ensino primário e várias instituições complementares da instrução pública. In: BARBOSA, Rui. Obras completas. Rio de Janeiro: Ministério da Educação e Saúde, v. X, t. I.

CAPRI, Roberto, (1909). Escola da vida - leituras clássicas, educativas e morais. Campinas: Tip. Popular Pires.

CARDOSO, Licínio, (1926). O ensino que nos convêm. Rio de Janeiro: Edição do Anuário do Brasil.

CARNEIRO LEÃO, Antonio, (1918). Pela educação rural. Rio de Janeiro: Typografia dos Tribunais.

CARVALHO, José Murilo de, (1989). Os bestializados; o Rio de Janeiro e a República que não foi. São Paulo: Cia. das Letras.

, (1998). Pontos e bordados; escritos de história e política. Belo Horizonte: Ed. UFMG.

CARVALHO, Marta de, (1989). A escola e a República. São Paulo: Brasiliense.

CASTORIADIS, C., (2000). Sur le politique de Platon. Paris: Seuil.

CHAGAS, Walnir, (1978). Educação brasileira: o ensino de $1^{\circ} \mathrm{e}$ $2^{\circ}$ graus; antes, agora e depois? São Paulo: Saraiva.

COSTA, Affonso, (1907). O ensino e a minha attitude na Câmara dos Deputados. Rio de Janeiro: Imprensa Nacional.

CUNHA AVELlaR, O. F., AVELlaR, P. A., (1915). Pontos de instrução cívica. Rio de Janeiro: Typ., Lith. e Papelaria Marques \& Cia.

FELICIANO, José, (1903). Escola Normal de São Paulo; a educação e a urbanidade. São Paulo: Tipografia do Diário Oficial.

FERNANDES, Florestan, (1966). Educação e sociedade no Brasil. São Paulo: Dominus/USP.

FRANCA, Leonel S. J., (1931). Ensino religioso e ensino leigo; aspectos pedagógicos, sociais e jurídicos. Rio de Janeiro: Editora Schmidt.
FRANCK, Adolpho, (1893). Elementos de educação cívica. Rio de Janeiro: Imprensa da Casa da Moeda.

HIRSCHMAN, Albert O., (1992). A retórica da intransigência: perversidade, futilidade, ameaça. São Paulo: Companhia das Letras.

HOBSBAWM, Eric, (1988). A era do capital (1848/1875). Rio de Janeiro: Paz e Terra, 1996.

. (1996), A era dos impérios (1875-1914). Rio de Janeiro: Paz e Terra.

LEMME, Paschoal, (1961). Educação democrática e progressista. São Paulo: Pluma.

NAGLE, Jorge, (1974). Educação e sociedade na I República. Rio de Janeiro: EPU/MEC.

PAIVA, Vanilda, (1973). Educação popular e educação de adultos; contribuição à história da educação brasileira. São Paulo: Loyola.

PEIXOTO, Júlio Afrânio, (1926). Cem anos de ensino primário. In: PEIXOTO, J. A. Livro do centenário da Câmara dos Deputados. Rio de Janeiro: Câmara dos Deputados.

QUAGLIO, Clemente, (1931). A educação existe? São Paulo: Faculdade de Pedologia.

RIBEIRO, Maria Luisa S., (1995). História da educação brasileira; a organização escolar. Campinas, SP: Autores Associados.

SAMPAIO DÓRIA, Antonio de, (1923). Questões de ensino; a reforma de 1920 em S. Paulo. São Paulo: Monteiro Lobato \& Cia. Editores, v. 1.

THOMPSON, E. P., (1987). A formação da classe operária inglesa. Rio de Janeiro: Paz e Terra.

VALLE, Lílian do, (1996). A escola e a Nação. São Paulo: Letras $\&$ Letras.

,(1997). A escola imaginária. Rio de Janeiro: DP\&A.

VASCONCELLOS, Aleixo, (1922). Luta contra o analfabetismo. Rio de Janeiro: s.n.t.

XAVIER, Maria Elizabete, RIBEIRO, Maria Luisa, NORONHA, Olinda Maria, (1994). História da educação; a escola no Brasil. São Paulo: FDT. 
not by his/her activity but by the readiness to be transformed by experience - a human passageway, submitted to a logic of passion. It affirms that the knowledge of experience is acquired in the relationship between knowledge and human, singular concrete life.

Key-words: experience, knowledge of experience, experience/sense.

Lílian do Valle

Bases antropológicas da cidadania brasileira: sobre escola pública e cidadania na Primeira República Devido às fragilidades de sua implantação, não são poucos, no Brasil, a tratarem o regime republicano como uma simples continuação do período monárquico. Igualmente correntes, as críticas à tradição de constituição, no país, de um Estado forte e monopolizador, concedem cores de fatalidade à idéia da formação histórica de um cidadão inexoravelmente passivo, tipo antropológico definitivo, a marcar os rígidos limites à democratização da sociedade brasileira. Seria, assim, cabal a impossibilidade de a escola pública formar cidadãos - todos os argumentos em contrário consistindo apenas em novas reedições do velho mito da demiurgia educacional? Ao tentar reunir os elementos para análise das construções antropológicas que estão na base da experiência de cidadania brasileira, esse artigo coloca em perspectiva aquela que sem dúvida é a primeira e a mais central das exigências democráticas: a afirmação incondicional e incondicionada da igualdade política dos cidadãos. Palavras-chave: escola pública, Primeira República, cidadania.

\section{Anthropological bases of Brazilian} citizenship: on the public school and citizenship in the $1^{\text {st }}$ Republic Many critics treat the republican regi- me in Brazil as a simple continuation of the monarchic period due to the fragility of its implantation. Critics of the tradition of the creation of a strong monopoly state in the country are equally common-place and accord tones of fatality to the idea of the historical formation of an inexorably passive type of definitively anthropological citizen, setting rigid limits to the democratisation of Brazilian society. The impossibility of the public school forming citizens would thus be proven - all the arguments to the contrary consisting only of re-editions of the old myth of the educational demiurge? By attempting to unite elements capable of analysing these anthropological constructions which form the base of the experience of Brazilian citizenship, this article brings into perspective what is without a doubt the first and most central of democratic requirements: the unconditional and unconditionable affirmation of the political equality of citizens.

Key-words: Public school, $I^{s t}$ Republic, citizenship.

\section{Nora Krawczyk}

\section{A sustentabilidade da reforma} educacional em questão: a posição dos organismos internacionais $\mathrm{O}$ artigo discute temas e questões abordados pelas produções dos organismos internacionais a partir de 1998 como diferentes dimensões de sustentabilidade das reformas educacionais na América Latina, que oferecem interessantes indícios dos aspectos que receberam e continuarão recebendo investimentos - técnicos e financeiros desses organismos. Pelo menos três dimensões preocupam bastante os organismos internacionais: a dimensão política, a dimensão financeira e a dimensão técnica. Para sua análise, fo- ram examinadas as publicações do Banco Mundial, da CEPAL, do PREAL, do BID, do IIPE/UNESCO e da OREALC/UNESCO, desde 1998 até 2001.

Palavras-chave: reforma educacional, América Latina, organismos internacionais.

The sustainability of the educational reform in question: the position of the international organisations

This article discusses the themes and questions dealt with in the productions of international organisations from 1998 onwards with relation to different dimensions of the sustainability of the educational reforms in Latin America which offer interesting signs of those aspects which have and will continue to receive technical and financial investments from such organisations. At least three dimensions concern the international organisations: the political, the financial and the technical dimensions. This analysis is based on an examination of publications by the World Bank, CEPAL, PREAL, BID, IIPE/ UNESCO and OREALC/UNESCO, from 1998 to 2001.

Key-words: educational reform, Latin America, international organisations.

Victor Vincent Valla

Pobreza, emoção e saúde: uma discussão sobre pentecostalismo e saúde no Brasil

No campo de educação e saúde tem surgido um debate sobre a origem dos problemas de saúde, o qual propõe que a origem desses problemas está basicamente relacionado com as emoções mais do que com bactérias ou vírus. A teoria do apoio social sugere que, se as emoções são relacionadas ao surgimento das doenças, as soluções também estão relacionadas com 